\title{
Seasonal infection intensity cycle of the parasite Perkinsus marinus (and an absence of Haplosporidium spp.) in oysters from a South Carolina salt marsh*
}

\author{
Michael P. Crosby ${ }^{1}$, Cynthia F. Roberts ${ }^{2}$ \\ ${ }^{1}$ Baruch Marine Field Laboratory, Belle W. Baruch Institute for Marine Biology and Coastal Research, University of South \\ Carolina, PO Box 1630, Georgetown, South Carolina 29442, USA \\ ${ }^{2}$ Department of Marine Science, Coastal Carolina College, PO Box 1954, Conway, South Carolina 29526, USA
}

\begin{abstract}
Investigation of the prevalence of the protozoan parasite Perkinsus marinus in populations of intertidal oysters (Crassostrea virginica) from a South Carolina salt marsh led to the finding of a distinct, 4 phase cycle of infection intensity. The cycle consisted of characteristic quiescent, pre-virulent, virulent and remission stages of infection. For the first time, P. marinus infection intensity in South Carolina oysters was found to have a statistically significant positive correlation with temperature and salinity, and a negative correlation with oyster condition index. Our data also indicated that $P$. marinus infection in adult oysters from South Carolina is not size dependent. Based on a limited, qualitative histopathological examination of oyster tissue samples, we found no evidence to indicate the presence of Haplosporidium spp. in the North Inlet salt marsh/estuary system. These results strongly suggest that highly localized mass mortalities of oysters in North Inlet have been due to virulent levels of $P$. marinus infections.
\end{abstract}

\section{INTRODUCTION}

Relatively high levels of very patchy, highly localized mortality of the American oyster Crassostrea virginica (Gmelin) were observed during early September 1987 in the North Inlet salt marsh/estuary, South Carolina, USA (qualitatively assessed by the authors to be $\sim 80 \%$ in some areas). Of all causes of oyster mortality (perhaps exclusive of harvesting), disease has been rated highest (Mackin 1959). We hypothesized that the oyster mortalities we observed were due to the apicomplexan protozoan Perkinsus (=Dermocystidium) marinus and possibly the haplosporidian protozoans Haplosporidium (= Minchinia) nelsoni and H. costalis. Descriptions and reviews of the taxonomy and pathology of these protozoans have been extensively presented elsewhere (Farley 1967, 1968, Perkins 1976 , 1987, Levine 1978, Levine et al. 1980, Andrews 1982, Sparks 1985, Cheng 1988).

\footnotetext{
- Contribution no. 804 of the Baruch Institute
}

Mortalities due to disease are often cyclic with peak mortalities occurring during limited periods of the year. Variations in the timing and intensity of these cycles is likely heavily influenced by changes in environmental parameters of different geographic regions. Thus, the epizootiology for Perkinsus marinus in the Chesapeake Bay (Andrews 1965) may not be the same in a South Carolina salt marsh. The elucidation of site-specific disease cycles is essential in order to conduct and correctly interpret scientific research using oysters from a given region, as well as for making appropriate management decisions concerning possible prevention or termination of epizootic events (Van Banning 1988). Past field studies of disease prevalence in bivalves have generally been limited in their temporal sensitivity and/or duration (Ray 1963a, Andrews 1965, 1967, Goggin \& Lester 1987, Craig et al. 1989). The potential for interaction between these protozoan diseases in bivalves has been rarely studied (Andrews 1965, 1967). There is a remarkable scarcity of reported data for these types of diseases in bivalves from South Carolina (Burrell et al. 1984) and a need for investiga- 
tions of the impact of $P$. marinus in South Carolina waters (Burrell et al. 1981).

Our original intent was to examine the seasonal prevalence and intensity cycles of both Perkinsus marinus and Haplosporidium nelsoni (and/or costalis) over a 2 yr period, at less than monthly intervals. The destruction of our laboratory and loss of stored histological oyster tissue slides and paraplast blocks by Hurricane Hugo in late September 1989 put an end to this study and prevented us from making a quantitative assessment of the prevalence and intensity of Haplosporidium spp. As a result, the purpose of this paper is to: (1) document the prevalence and 4 phase cycle of infection intensity for $P$. marinus in oysters from a relatively pristine South Carolina salt marsh; (2) report the limited qualitative results of histological examination for Haplosporidium spp. prevalence in these same oysters; and (3) discuss which protozoan is the likely cause of the observed oyster mortalities.

\section{MATERIALS AND METHODS}

Beginning in March 1988, 12 adult oysters (Crassostrea virginica) were collected from the lower intertidal zone at each of 2 collection sites in the salt marsh of North Inlet estuary, South Carolina, USA. North Inlet is a pristine system that has been a National Science Foundation long-term ecological research site for the past 10 yr. Collections were made every 2 to $3 \mathrm{wk}$. After each oyster was scrubbed clean of all epibionts, individual shell heights and live whole animal volume were determined. Oysters were then opened, the soft body tissue removed from the shell and a transverse cross section of tissue ( $\sim 4 \mathrm{~mm}$ thick with dorsal edge of cut beginning at the junction of the palps and gill) taken for histopathological examination for Haplosporidium spp. Wet weight of the tissue cross section was determined prior to placing the tissue in a formalin acetic acid (FAA) fixative $(917 \mathrm{ml} 50 \%$ ethyl alcohol + $23 \mathrm{ml}$ glacial acetic acid $+60 \mathrm{ml} 40 \%$ formalin). The tissue was then processed for histological examination according to methods outlined by Howard \& Smith (1983). Tissues were taken for histological examination at approximately $8 \mathrm{wk}$ intervals, while examination of tissues for Perkinsus marinus occurred every 2 to $3 \mathrm{wk}$. The labial palps and terminal portion of the rectum were removed for $P$. marinus infection intensity determinations (see below for technique). The remaining soft body tissue was dried $\left(80^{\circ} \mathrm{C}, 48 \mathrm{~h}\right)$ and weighed, while the cleaned, empty shell volume was determined. The wet weight of the labial palps was determined prior to being placed into the culture medium. Dry weights of palps and tissue taken for histopathology were determined via the regression equation:

$$
\begin{gathered}
\log _{10} \text { dry wt }=0.427+(0.571)\left(\log _{10} \text { wet wt }\right) \\
p<0.0001, r=0.922, R^{2}=0.851
\end{gathered}
$$

and added to the soft body tissue dry weight for an accurate measure of total soft body tissue dry weight. The amount of dry weight lost by removal of the terminal portion of the rectum ( $\sim 3$ to $4 \mathrm{~mm}$ in length) was not significant. In May 1989, a Kendall rank correlation analysis demonstrated a significant $(p<0.001)$ correlation between $P$. marinus infection intensities found in an individual oyster's palps and rectum tissues. In addition, a Mann-Whitney $U$ analysis revealed a significantly higher $(\mathrm{p}<0.001)$ mean ranking of rectum infection intensities over palps intensities. Thus, beginning in June 1989, palps tissues were no longer excised for $P$. marinus infection intensity determination so that the number of oysters collected from each site and examinations for rectal infection intensities could be doubled ( $n=25$ for each site). The study was terminated at the end of September 1989 by Hurricane Hugo.

Initially, condition index (CI) was determined volumetrically via the equation:

$$
\mathrm{CI}=\frac{\text { dry soft body tissue }(\mathrm{g}) \times 1000}{\text { internal shell cavity vol. }(\mathrm{ml})}
$$

However, a concurrent study (Crosby \& Gale in press) demonstrated that a gravimetric methodology was superior to volumetric methods in reducing errors, increasing levels of sensitivity and reducing time of measurements. Gravimetric and volumetric methods were also found to be highly correlated and not significantly different. Beginning in June 1989, therefore, we elected to begin using gravimetric methods to determine CI via the equation recommended by Crosby and Gale (in press), i.e.

$$
\mathrm{CI}=\frac{\text { dry soft body tissue }(\mathrm{g}) \times 1000}{\text { internal shell cavity capacity }(\mathrm{g})}
$$

The culturing technique and examination for Perkinsus marinus consisted of incubation of the sample tissue in fluid thioglycolate media as described by Ray (1963b). Infection intensity level for each oyster was assigned on a scale from 0 to 6 as described by Quick \& Mackin (1971), with 0 being an absence of hypnospores and 6 indicating all fields almost black with stained hypnospores. Monthly mean infection intensity includes all oysters sampled in a given month. Monthly mean water temperatures and salinities were derived from daily sampling at a site in North Inlet, midway between each of the oyster sampling sites. All statistical analyses were performed with a Macintosh SE computer using the StatView 512+ statistical package (Gagnon \& Feldman 1986). 
Table 1. Mean (and SE) monthly Perkinsus marinus infection intensity in rectal tissue of Crassostrea virginica, total number of oysters sampled $(\mathrm{N})$, condition index $(\mathrm{CI})$, dry soft tissue weight (in $\mathrm{g})$, water temperature $(\mathrm{T})$ and salinity $(\mathrm{S})$

\begin{tabular}{|c|c|c|c|c|c|c|}
\hline Month & P. marinus & $\mathrm{N}$ & $\mathrm{CI}$ & Tissue & $\mathrm{T}\left({ }^{\circ} \mathrm{C}\right)$ & $\mathrm{S}(\%)$ \\
\hline Jan & $2.62(0.19)$ & 24 & $90.97 \quad(5.01)$ & $1.32(0.09)$ & 11.1 & 34.2 \\
\hline Feb & $2.04(0.13)$ & 48 & $75.89(4.25)$ & $1.11(0.06)$ & 11.5 & 33.9 \\
\hline Mar & $2.00(0.15)$ & 48 & $76.22(4.41)$ & $1.05(0.04)$ & 13.5 & 29.9 \\
\hline Apr & $1.53(0.12)$ & 72 & $93.09(6.07)$ & $1.16(0.05)$ & 17.9 & 29.3 \\
\hline May & $2.50(0.20)$ & 48 & $81.51 \quad(5.34)$ & $1.08(0.06)$ & 22.1 & 30.2 \\
\hline Jun & $3.28(0.10)$ & 148 & $81.80(2.68)$ & $1.00(0.03)$ & 26.9 & 32.6 \\
\hline Jul & $3.29(0.12)$ & 96 & $74.12(2.80)$ & $1.02(0.04)$ & 28.2 & 33.0 \\
\hline Aug & $3.81(0.10)$ & 148 & $65.57(1.70)$ & $0.95(0.03)$ & 28.2 & 33.1 \\
\hline Sep & $3.74(0.12)$ & 98 & 61.45 & $1.00(0.03)$ & 26.1 & 31.6 \\
\hline Oct & $3.78(0.31)$ & 23 & $69.45(6.44)$ & $1.03(0.07)$ & 19.2 & 34.6 \\
\hline Nov & $2.88(0.30)$ & 24 & $95.04 \quad(9.47)$ & $1.00(0.06)$ & 15.9 & 34.2 \\
\hline Dec & $2.67(0.30)$ & 24 & $80.70(7.84)$ & $0.89(0.08)$ & 9.8 & 34.9 \\
\hline
\end{tabular}

Table 2. Mean (and SE) monthly Perkinsus marinus infection intensity in rectal tissue of Crassostrea virginica, number of oysters ( $\mathrm{N})$, range of observed intensity levels, and prevelence of infection in oyster. Months with infection intensity levels found to be not significantly different via ANOVA with Fisher's PLSD comparisons are given the same letter under the heading PLSD. Level of significance set at $p \leq 0.05$

\begin{tabular}{|llrlrl|}
\hline Month & P. marinus & N & Range & $\begin{array}{r}\text { Prevelence } \\
(\%)\end{array}$ & PLSD \\
\hline Jan & $2.62(0.19)$ & 24 & 1 to 4 & 100.00 & A, B \\
Feb & $2.04(0.13)$ & 48 & 0 to 5 & 95.83 & B, C \\
Mar & $2.00(0.15)$ & 48 & 0 to 5 & 93.75 & C \\
Apr & $1.53(0.12)$ & 72 & 0 to 5 & 87.50 & \\
May & $2.50(0.20)$ & 48 & 0 to 5 & 97.02 & A, B \\
Jun & $3.28(0.10)$ & 148 & 1 to 6 & 100.00 & D, E \\
Jul & $3.29(0.12)$ & 96 & 1 to 6 & 100.00 & D, E \\
Aug & $3.81(0.10)$ & 148 & 1 to 6 & 100.00 & F \\
Sep & $3.74(0.12)$ & 98 & 1 to 6 & 100.00 & F \\
Oct & $3.78(0.31)$ & 23 & 1 to 5 & 100.00 & D, F \\
Nov & $2.88(0.30)$ & 24 & 1 to 5 & 100.00 & A, E \\
Dec & $2.67(0.30)$ & 24 & 1 to 5 & 100.00 & A \\
\hline
\end{tabular}

\section{RESULTS}

Differences between sites in Perkinsus marinus infection intensities were examined for each month by analyses of variance (ANOVA). Results indicated no significant difference between sites for monthly intensity levels. Data from the 2 sites were therefore, pooled for further analyses. Monthly means for infection intensity, CI, dry soft body tissue weight, water temperature and salinity are given in Table 1 . An ANOVA with Fisher's protected least squares difference (PLSD) comparison was conducted in order to determine any significant differences between monthly mean infection intensities. Results of this analysis, along with monthly mean and range of observed infection intensity levels are presented in Table 2. Total P. marinus prevalence for all oysters examined was $98.1 \%$. Only 4 mo exhib-
Table 3. Kendall rank correlation coefficient matrix between Perkinsus marinus infection intensity in rectal tissue of Crassostrea virginica, condition index $(\mathrm{CI})$, height $(\mathrm{HT})$, dry tissue weight (Tissue), water temperature $\left(\mathrm{T}{ }^{\circ} \mathrm{C}\right)$, and salinity $(\mathrm{S}, \%)$. Abbreviations are: (t) tau corrected for ties; $(p)$ level of significance; (n) no. cases; (ns) not significant at $\mathrm{p}>0.05$

\begin{tabular}{|lccccc|}
\hline & $\mathrm{S}$ & $\mathrm{T}$ & Tissue & $\mathrm{HT}$ & $\mathrm{CI}$ \\
\hline P. marinus & & & & & \\
$\mathrm{t}$ & 0.094 & 0.283 & -0.098 & $\mathrm{nS}$ & -0.167 \\
$\mathrm{p}$ & $<0.001$ & $<0.001$ & $<0.001$ & & $<0.001$ \\
$\mathrm{n}$ & 801 & 801 & 753 & & 716 \\
$\mathrm{CI}$ & & & & & \\
$\mathrm{t}$ & $\mathrm{ns}$ & $\mathrm{ns}$ & 0.277 & -0.128 & \\
$\mathrm{p}$ & & & $<0.001$ & $<0.001$ & \\
$\mathrm{n}$ & & & 761 & 739 & \\
$\mathrm{HT}$ & & & & & \\
$\mathrm{t}$ & $\mathrm{ns}$ & -0.099 & 0.236 & & \\
$\mathrm{p}$ & & $<0.001$ & $<0.001$ & & \\
$\mathrm{n}$ & & 824 & 776 & & \\
Tissue & & & & & \\
$\mathrm{t}$ & -0.112 & -0.063 & & \\
$\mathrm{p}$ & $<0.001$ & $<0.01$ & & \\
$\mathrm{n}$ & 777 & 777 & & \\
$\mathrm{~T}$ & & & & \\
$\mathrm{t}$ & 0.060 & & & \\
$\mathrm{p}$ & $<0.02$ & & & \\
$\mathrm{n}$ & 825 & & & \\
$\mathrm{n}$ & & & & \\
\hline
\end{tabular}

ited prevalence levels less than $100 \%$ : $95.8 \%$ in February, $93.8 \%$ in March, $87.5 \%$ in April and $97.9 \%$ in May.

A results matrix of the Kendall rank correlation analyses between infection intensity, CI, shell height, dry soft body tissue weight, water temperature and salinity are presented in Table 3. Salinity and temperature were positively correlated with infection intensity. Dry soft-body tissue weight and CI were negatively correlated with infection intensity. No significant correlation 
was found between shell height and infection intensity. Regression analyses indicated that only $2 \%$ of dry soft body tissue and $5 \%$ of CI variability was explained by infection intensity. Infection intensity combined with shell height explained $13.9 \%$ of dry soft body tissue and $8.8 \%$ of CI variability. Shell heights ranged from 6.7 to $16.5 \mathrm{~cm}$, with a mean of $10.1 \mathrm{~cm}(\mathrm{SE}=1.0 \mathrm{~cm})$. However, $63 \%$ of examined oysters had shell heights between 8.7 and $11.6 \mathrm{~cm}$, and $88 \%$ were between 7.7 and $12.6 \mathrm{~cm}$. Temperature was found to explain $16.7 \%$, while salinity explained only $3.6 \%$ of the infection intensity variability.

Random histological samples of oysters collected in June 1988 were examined microscopically prior to the loss of these samples in Hurricane Hugo. No histological evidence for the presence of Haplosporidium spp. was seen in the approximately 25 samples surveyed.

\section{DISCUSSION}

Examination of the Perkinsus marinus infection intensity data presented in Table 1 and 2 has led to our conclusion that the epizootiology of $P$. marinus in South Carolina oysters exists in a 4 phase cycle which we present in Fig. 1. Phase 1 of this cycle may be viewed as a period of quiescence. The quiescent phase of infection intensity (February, March, April) is characterized by the lowest levels of both mean intensity and prevalence, as well as each month in the phase having individual oysters exhibiting no infection at all. Phase 2 is the pre-virulent period (May, June, July) and is marked by a dramatic and rapid increase in monthly mean intensity levels along with a transition from a maximum observed intensity level of 5 to the maximum, 6. Phase 3 is the virulent stage of $P$. marinus

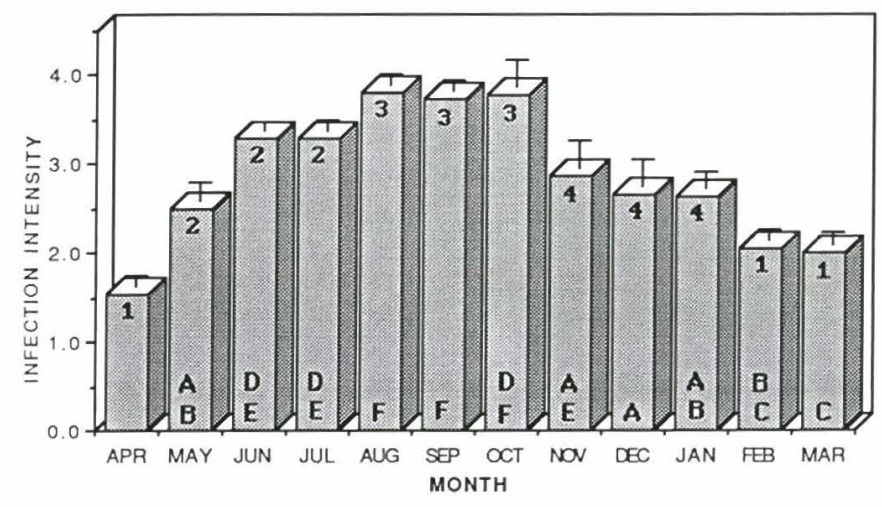

Fig. 1. Mean monthly (+ SE) Perkinsus marinus infection intensity in oysters from North Inlet, South Carolina. Months having the same letter were not found to be significantly different via ANOVA with Fisher's PLSD comparisons. Numbers within each monthly column indicate the infection cycle phase, where: (1) quiescent; (2) pre-virulent; (3) virulent; and (4) remission. (See text for further details) infection in Crassostrea virginica. The virulent phase (August, September, October) is characterized by the peak of infection intensity and no occurrence of oysters free of infection in each of the inclusive months. The fourth phase of the cycle (November, December, January) is a remission stage when monthly mean infection intensity drops dramatically and all oysters examined had intensity levels of less than 6 .

The 2 physical factors that were examined in this study, temperature and salinity, were very highly correlated $(\mathrm{p}<0.001)$ with Perkinsus marinus infection intensity in Crassostrea virginica. It was earlier determined (see Results) that changes in salinity could only account for $3.6 \%$ of the variability in infection intensity, while temperature accounted for much more $(16.7 \%)$ of infection intensity changes. When monthly mean temperature and infection intensity are plotted together (Fig. 2) it becomes apparent that increases and decreases in water temperature 'lead' similar changes in infection intensity. Although past reports of general, non-statistical (Mackin 1962, Andrews 1965, 1967) and more specific, yet still non-statistical (Chu \& Greene 1989) studies have indicated a positive correlation between water temperature and $P$. marinus infection intensity levels in $C$. virginica, the limited number of field studies using statistical analyses of the data have found no statistically significant relationship between water temperature and infection intensity (Burrell et al. 1984, Craig et al. 1989). The contrasting finding in our study of a statistically significant $(p<0.001)$ positive relationship between water temperature and infection intensity supports the inferred correlations of the above studies. The difference of our results from those of Burrell et al. (1984) and Craig et al. (1989) are likely due to the manner in which water temperature data was collected in the 3 studies. Both Burrell et al. and Craig et al. measured temperature on the day of oyster collection, which yields only an instantaneous point of measurement in time. Our water temperature data were an integration of daily measurements over month-long periods of time, and as such are much more representative of the history of environmental exposure which both the protozoan and oyster have been exposed to prior to sampling. The importance of having a knowledge of recent environmental exposure history is graphically evident in Fig. 2 .

Our study is the first to document a statistically significant relationship between Crassostrea virginica CI and Perkinsus marinus infection intensity levels in South Carolina. A negative correlation between spawning and CI in South Carolina oysters has been previously inferred (McNulty 1953). However, oysters in North Inlet have a peak spawning event in April/ May (Kenny et al. unpubl. data) during the quiescent and early pre-virulent phases of $P$. marinus infection. 


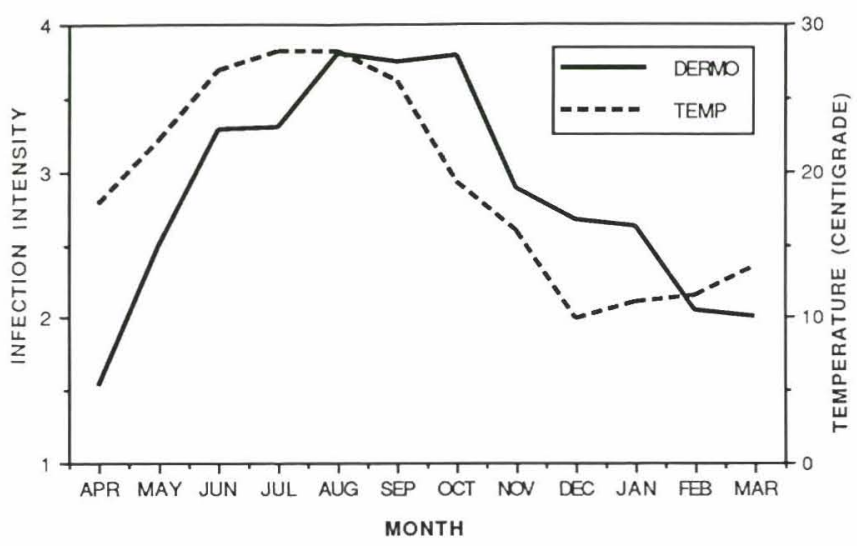

Fig. 2. Water temperature fluctuations associated with observed Perkinsus marinus (DERMO) infection intensity cycle in oysters from North Inlet, South Carolina

Both oyster dry soft body tissue weight and CI were significantly $(\mathrm{p}<0.001)$ negatively correlated with $P$. marinus infection intensity level. These relationships agree with the results of previous published reports on $P$. marinus parasitism in $C$. virginica outside of South Carolina (Menzel \& Hopkins 1955, Quick \& Mackin 1971, Craig et al. 1989). The exact mechanism(s) by which $P$. marinus causes decreases in $C$. virginica softbody tissue and $\mathrm{CI}$ have not yet been clearly elucidated. There is evidence that $P$. marinus infection alters fat metabolism (Stein \& Mackin 1955) and free amino acid composition (Soniat \& Koenig 1982) in C. virginica. It is possible that our findings are a result of systemic invasion by the protozoan with damage occurring to the oyster's blood sinuses and connective tissue (Mackin 1951, Sparks 1985). The oyster must then reallocate energy from growth and normal maintenance metabolism to resisting the parasitism, i.e. increase in phagocytotic activity and repairing the tissue damage, while concurrently having a compromised system with which to carry out defensive and repair activities.

It is generally assumed (Ray 1963a, Burrell et al. 1984) that Perkinsus marinus infection is positively correlated with oyster age (= height). White et al. (1989) reported that large oysters $(>5 \mathrm{~cm}$ ) were infected 3 to 4 times as frequently by $P$. marinus as smaller oysters, while Andrews (1967) presented evidence that disease-free oysters require 1 to $3 \mathrm{yr}$ to acquire the disease. Our study found no significant relationship between Crassostrea virginica age and infection intensity. The minimum oyster shell height in our study was $6.7 \mathrm{~cm}$ (see Results), so that the minimum age oyster was 2-yrold (Crosby unpubl. data). Although all oysters examined in our study were greater than 2 yr of age, it is nevertheless interesting that over a size range of 10 $\mathrm{cm}$ no significant relationship was found between age and infection intensity. Our data then, indicate that $P$. marinus infection in adult oysters from South Carolina is not size dependent. In order for a definitive Conclusion regrading the lack of correlation between oyster age and infection, however, a single time point study across a sufficiently large number of oysters of different ages may be required.

On the basis of our very limited, qualitative histopathological examination of oyster tissue samples, we have no evidence to indicate the presence of Haplosporidium spp. in the North Inlet salt marsh/ estuary system. This parasite has been found to the north (Andrews 1982) and, to a limited degree, to the south (Kern pers. comm.) of South Carolina. To date, only $\ll 1 \%$ of a sample of Crassostrea virginica from the region of the South Carolina-Georgia border have shown any $H$. nelsoni in South Carolina (Burrell pers. comm.). If Haplosporidium spp. were infecting oysters in North Inlet one would expect much less patchy, nonlocalized high levels of mortality to have occurred. This is due to the Haplosporidium spp. parasite not being host-density dependent (Perkins 1987), as well as it killing it's host rapidly and dispersing quickly within a system (Andrews 1982). The negative histopathological examination for Haplosporidium spp. and the lack of characteristic epizootiology of Haplosporidium spp. being noted in the oyster mortality patterns we observed in North Inlet are strong evidence that the significant contributing factor for the patchy, localized mortalities was virulent levels of Perkinsus marinus infection rather than Haplosporidium spp. However, the histopathological samples we examined were only from the month of June, which is not a period that Haplosporidium spp. would be expected to be most prevalent, and a 'border-line' area of Haplosporidium spp. infestation may exhibit patchy mortalities (Kern pers. comm.). We therefore appreciate the need for, and recommend that histopathological surveys for Haplosporidium spp. be re-instated in North Inlet, in particular, and be expanded throughout the South Carolina region.

Although water temperature and salinity account for approximately $20 \%$ of the variability in Perkinsus marinus infection intensity levels in Crassostrea virginica, much of the remaining intensity variability is likely to due to the physiological state, i.e. scope for growth, of both oyster and protozoan and the interaction between the 2 with their environment. To more clearly understand the mechanisms of marine bivalve diseases unique to South Carolina, studies dealing with these interactions, such as Andrews (1967), Ford (1985), Newell (1985), Fisher $(1987,1988)$, Barber et al. (1988), and Chu \& Greene (1989), need to be conducted in this geographic region. One of us (M. P. C.) has just completed a nearly $3 \mathrm{yr}$ investigation of the in situ ecophysiology of oyster populations from the North Inlet collection sites examined in this study, the results 
of which are being prepared for publication. It is hoped that the combined efforts of our 2 studies will serve as a basis for a much needed future expansion of studies dealing with the ecological effects of diseases in bivalves in the South Carolina region.

Acknowledgements. We would like to thank Mr Paul Kenny for his help with collecting many of the oysters and preparing media used in this study and Ms Yvonne Bobo for processing and staining many of the tissue sections. C. F. R. was supported in part by a National Science Foundation Research Experience for Undergraduates grant. M. P. C. would like to thank both the Belle W. Baruch Foundation and the B. W. Baruch Institute for Marine Biology and Coastal Research for their financial support of this project.

\section{LITERATURE CITED}

Andrews, J. D. (1965). Infection experiments in Nature with Dermocystidium marinum in Chesapeake Bay. Chesapeake Sci. 6: 60-67

Andrews, J. D. (1967). Interaction of two diseases of oysters in natural waters. Proc. natn. Shellfish Ass. 57: 38-59

Andrews, J. D. (1982). Epizootiology of late summer and fall infections of oysters by Haplosporidium nelsoni, and comparison to annual life cycle of Haplosporidium costalis, a typical Haplosporidan. J. Shellfish Res. 2: 15-23

Barber, B. J., Ford, S. E., Haskin, H. H. (1988). Effects of the parasite MSX (Haplosporidium nelsoni) on oyster (Crassostrea virginica) energy metabolism. I. Condition index and relative fecundity. J. Shellfish Res. 7: 25-32

Burrell, V. G. Jr, Bobo, M. Y., Manzi, J. J. (1984). A comparison of seasonal incidence and intensity of Perkinsus marinus between subtidal and intertidal oyster populations in South Carolina. J. Wld Maricult. Soc. 15: 301-309

Burrell, V. G. Jr, Manzi, J. J., Carson, W. Z. (1981). Growth and mortality of two types of seed oysters from the Wando River, South Carolina. J. Shellfish Res. 1: 1-7

Cheng, T. C. (1988). Strategies employed by parasites of marine bivalves to effect successful establishment in hosts. Am. Fish. Soc. Spec. Publ. 18: 112-129

Chu, F.-L. E., Greene, K. H. (1989). Effect of temperature and salinity on in vitro culture of the oyster pathogen, Perkinsus marinus (Apicomplexa: Perkinsea). J. Invertebr. Path. 53: $260-268$

Craig, A., Powell, E. N., Fay, R. R., Brooks, J. M. (1989). Distribution of Perkinsus marinus in Gulf Coast oyster populations. Estuaries 12: 82-91

Crosby, M. P., Gale, L. D. (in press). A review of the historical lack of uniformity for and an evaluation of bivalve condition index methodologies with a suggested standard method to be used in the future. J. Shellfish Res. 9 (1): (in press)

Farley, C. A. (1967). A proposed life cycle of Minchinia nelsoni (Haplosporida, Haplosporidiidae) in the American oyster Crassostrea virginica. J. Protozool. 14: 616-625

Farley, C. A. (1968). Minchinia nelsoni (Haplosporida) disease syndrome in the American oyster Crassostrea virginica. J. Protozool. 15: 585-599

Fisher, W. S. (1987). Environmental effects on defense mechanisms. In: Fisher, W. S., Figueras, A. J. (eds.) Marine bivalve pathology. Maryland Sea Grant Publ. College Park, MD. UM-SG-TS-87-02, p. 56-58

Fisher, W. S. (1988). Environmental influence on bivalve hemocyte function. Am. Fish. Soc. Spec. Publ. 18: 225-237
Ford, S. E. (1985). Effects of salinity on survival of the MSX parasite Haplosporidium nelsoni (Haskin, Stauber and Mackin) in oysters. J. Shellfish Res. 5: 85-90

Gagnon, J., Feldman, D. S. (1986). StatView, the professional, graphic, statistics utility. BrainPower Inc., California

Goggin, C. L., Lester, R. J. G. (1987). Occurrence of Perkinsus species (Protozoa, Apicomplexa) in bivalves from the Great Barrier Reef. Dis. aquat. Org. 3: 113-117

Haskin, H. H., Stauber, L. A., Mackin, J. A. (1966). Minchinia nelsoni n. sp. (Haplosporida, Haplosporididae): causative organism agent of the Delaware Bay oyster epizootic. Science 153: 1414-1416

Howard, D. W., Smith, C. S. (1983). Histological techniques for marine bivalve molluscs. NOAA Tech. Memo. U.S. Dep. Commerce 25: 1-97

Lauckner, G. (1983). Diseases of Mollusca: Bivalvia. In: Kinne, O. (ed.) Diseases of marine animals, vol. 2. Biologische Anstalt Helgoland, Hamburg, p. 477-961

Levine, N. D. (1978). Perkinsus gen. n. and other new taxa in the protozoan phylum Apicomplexa. J. Parasit. 64: 549

Levine, N. D., Corliss, J. O., Cox, F. E. G., Deroux, G., Grain, J., Honigberg, B. M., Leedale, G. F., Loeblich, A. R. III, Lom, J., Lynn, D., Merinfeld, E. G., Page, F. C., Poljansky, G., Sprague, V., Vavra, J., Wallace, F. G. (1980). A newly revised classification of the Protozoa. J. Protozool. 27: 37-58

Mackin, J. G. (1951). Histopathology of infection of Crassostrea virginica (Gmelin) by Dermocystidium marinum Mackin, Owen and Collier. Bull. mar. Sci. Gulf Caribb. 1: $72-87$

Mackin, J. C. (1959). Mortalities of oysters. Proc. natn. Shellfish. Ass. 50: 21-40

Mackin, J. G. (1962). Oyster disease caused by Dermocystidium marinum and other microorganisms in Louisiana. Publs Inst. mar. Sci. Univ. Tex. 7: 132-229

McNulty, J. K. (1953). Seasonal and vertical patterns of oyster setting of Wadmalaw Island, S. C. Contr. Bears Bluff Lab. 15: $1-17$

Menzel, R. W., Hopkins, S. H. (1955). The growth of oysters parasitized by the fungus Dermocystidium marinum and by the trematode Bucephalus cuculus. J. Parasitol. 41: 333-342

Newell, R. I. E. (1985). Physiological effects of the MSX parasite Haplosporidium nelsoni (Haskin, Stauber and Mackin) on the American oyster Crassostrea virginica (Gmelin). J. Shellfish Res. 5: 91-96

Perkins, F. O. (1976). Dermocystidium marinum infection in oysters. Mar. Fish. Rev. 38 (10): 19-31

Perkins, F. O. (1987). Protistan parasites of commercially significant marine bivalve molluscs - life cycles, ultrastructure, and phylogeny. Aquaculture 67: 240-243

Quick, J. A. Jr, Mackin, J. G. (1971). Oyster parasitism by Labyrinthomyxa marina in Florida. Fla dept. natural resources, Mar. Res. Lab. Prof. Pape Ser. 13: 1-55

Ray, S. M. (1963a). Notes on the occurrence of Dermocystidium marinum on the Gulf of Mexico coast during 1961 and 1962. Proc. natn. Shellfish. Ass. 54: 45-54

Ray, S. M. (1963b). A review of the culture method for detecting Dermocystidium marinum with suggested modifications and precautions. Proc. natn. Shellfish. Ass. 54: 55-69

Soniat, T. M., Koenig, M. L. (1982). The effects of parasitism by Perkinsus marinus on the free amino acid composition of Crassostrea virginica mantle tissue. J. Shellfish Res. 2: 25-28

Sparks, A. K. (1985). Synopsis of invertebrate pathology: exclusive of insects. Elsevier Science Publ., Amsterdam

Stein, J. E., Mackin, J. G. (1955). A study of the nature of pigment cells of oysters and the relation of the fungus 
disease caused by Dermocystidium marinum. Tex. J. Sci. 7: $422-429$

Van Banning, P. (1988). Management strategies to control diseases in the Dutch culture of edible oysters. Am. Fish. Soc. Spec. Publ. 18: 243-245

Responsible Subject Editor: Dr A. K. Sparks, Seattle, Washington, USA
White, M. E., Powell, E. N., Wilson, E. A., Ray, S. M. (1989). The spatial distribution of Perkinsus marinus, a protozoan parasite, in relation to its oyster host (Crassostrea virginica) and an ectoparasitic gastropod (Boonea impressa). J. mar. biol. Ass. U.K. 69: 703-717

Manuscript first received: January 25, 1990 Revised version accepted: June 27, 1990 